\title{
The Portrait of Rural Early Childhood Education (ECE) Quality in the Digital Era After One Village One ECE Policy Program
}

\author{
Edi Waluyo, Sri S. Dewanti Handayani and Diana \\ Universitas Negeri Semarang, Semarang, Indonesia \\ e-mail: waluyo_edi@gmail.com
}

\begin{abstract}
This research focuses on the portraits of family and community participation in early childhood education (ECE) after one village one ECE policy program is implemented in rural ECE institutions. Portrait of the quality standard of rural ECE develops the achievement of 8 standards in ECE institutions in the form of: Level of Child Development Achievement Standards; Content Standards; Process Standards; Assessment Standards; Educators and Education Personnel Standards; Facilities and Infrastructure Standards; Management Standards; and Financing Standards. The implementation of one village one ECE program as a whole requires a close and more orderly collaboration between the village government, ECE institutions and the community so that the right solutions and policies can be formed together to solve the problems in ECE.
\end{abstract}

Keywords: Quality, Rural ECE, Policy

\section{INTRODUCTION}

The success of an educational institution is also determined by the management of the institution. Education management is the process of collaborating with a group of people to achieve a common goal. The process includes planning, organizing, controlling, and monitoring. Educators, students, curriculum and learning environment are managed in such a way that ultimately produces output that is appropriate to the learning objectives. Management activities are the main responsibility of the educational institution leaders.

The development of ECE institutions is always accompanied by quality demands. The development of quality ECE institutions has always been a reference for ECE institutions that exist in the surrounding environment and even become a reference for institutions in other areas. In addition, to demand from ECE institutions to become quality institutions, the government also provides references in the development of standardized ECE institutions.
Law Number 20 of 2003 concerning the National Education System Chapter I Article 1 paragraph 14 states that ECE is a coaching effort aimed at children from birth to 6 years of age carried out through educational stimuli to help the growth of both physical and spiritual development so that children have learning readiness in entering further education. This law mandates that education must be prepared in a planned and holistic manner as the basis for the child to enter further education.

Village law is a set of rules regarding the implementation of village government with consideration that it has developed in various forms so that it needs to be protected and empowered to be strong, advanced, independent and democratic so as to create a strong foundation in implementing governance and development towards a just, prosperous and fulfilled society. (Village Law No. 6 of 2014).

According to the Director General of ECENI affirming the Ministry of Education and Culture's 2012 vision of strengthening services with one village one ECE policy program, the effort to 
implement one village of at least one ECE is a must and expects the regional government to support the program.

The Village Law explains the purpose of village development is to improve the welfare of rural communities and the quality of human life and poverty alleviation through the fulfillment of basic needs, the development of village facilities and infrastructure, the development of local economic potential, and the sustainable use of natural and environmental resources.

Based on the Regulation of the Minister of Villages, Development of Disadvantaged Regions, and Transmigration of the Republic of Indonesia Number 22 of 2016 concerning Determination of Priority for the use of village funds in 2017, it is stated that Village development activities that can be funded by Village Funds are as follows: Procurement, development, development and maintenance of educational infrastructure and culture, among others: ECE buildings; books and other ECE learning equipments; and a vehicle for children's play in ECE.

\section{METHOD}

In general because it seeks to uncover the perspective of the research subject as a whole, this research prioritizes an exploratory-participatory approach, or 'co-constructive', in which knowledge and understanding of the problem under study is built together between the subject and the researcher (Blaise, 2005)

This study intends to explore construction "Portrait of rural ECE quality after one village one ECE policy program according to the head / manager of ECE, teachers, village officials and parents. Data collection techniques include questionnaires, documentation, in-depth interviews, observation, and focus group discussions. Using questionnaires to give an initial overview of how family and community participation in ECE development are, portraits the quality of rural ECE and find out how ECE is part of rural development. The questionnaire was designed based on "theoretical-official" construction of the one village one ECE policy program. In-depth interviews were conducted on selected subjects to deepen findings that were considered important.

\section{RESULT AND DISCUSSION}

The community up to now has not been fully familiar with early childhood education. It is often debated between ECE and kindergarten. Whereas the difference is actually in terms of education channels, between formal and non-formal education such as Child Care, Play Groups and Kindergartens. These institutions are then called early childhood education.

Described in Law Number 20 of 2003 concerning the National Education System in Chapter I Article 1 paragraph 14 states that ECE is an effort to guide children from birth to 6 years of age through educational stimuli to help physical growth and development and spiritually so that children have learning readiness in entering further education. This law mandates that early childhood education must be prepared in a planned and holistic manner as the basis for children entering further education.

Early childhood education has an important role in improving human resources. Early age is a very special time for children development. As educators, parents are very interested in fulfilling the essential needs of children in a good and comprehensive manner. This is where skilled hands are needed to provide stimulation for early childhood so that they grow optimally in accordance with the stage of their age.

Until now, although ECE has been recognized as a legitimate part of the national education system, in reality government investment in the early childhood education sector still needs to be improved. The size of the budget given can certainly affect the quality of ECE in general, for example those related to building construction, facilities and infrastructure to support education and increase the capacity and quality of teachers.

Strengthening services with one village one $\mathrm{ECE}$, is a necessity with the hope that children in rural areas are served early education. Applying one village at least one ECE requires a lot of participation from various parties including the government at the village level.

\subsection{The Portrait of Rural ECE in Digital Era}

The quality of rural ECE has become a necessity, and is a part that should be considered and prioritized by the central government to regional governments, when Indonesia will celebrate Golden Indonesia in 2045 with full achievements based on the indicator targets expected by the government.

The portrait of rural ECE quality is one indicator of education development in Indonesia. Progressing education should start from advancing the education 
of children of their age by providing the best kinds of facilitaties from the government and the private sector in handling all aspects related to early childhood education in Indonesia.

Towards quality ECE portraits, it is not as easy as blinking our eyes, this happens because in the field the community has not fully explored the world of ECE well, especially in government policies set out in the National Education System Law, ECE is divided into various formal and non-formal ECE channels. This is also a matter of public debate which until now has not led to the settlement and mutual understanding.

The quality of ECE is determined by the quality of services in the institution. This shows that quality ECE is supported by professional teachers in the field of early childhood education, adequate facilities and infrastructure to provide the best facilitaties and stimulation for children and how institutional management also provides support to give the best service to their students.

\begin{tabular}{|c|c|c|}
\hline NO & STANDARDS & RESULT \\
\hline 1 & $\begin{array}{l}\text { Level of Child Development } \\
\text { Achievement }(S T T P A)\end{array}$ & $\begin{array}{l}\text { 1. ECE institutions strive to develop special STPPA that is made for } \\
\text { children with special needs (fill in the limits of criteria determined by } \\
\text { the school) because every school year there are students with special } \\
\text { needs } \\
\text { 2. Institutions in the development of STPPA based on Minister of } \\
\text { Education and Culture Regulation No. } 137 \text { of } 2014 \text { can be further } \\
\text { developed by institutions based on the curriculum and outputs planned } \\
\text { by the institution. } \\
\text { 3. Institutions need to conduct a needs analysis to develop a standard } \\
\text { level of achievement of child development so that the results can be } \\
\text { used as predictions for the development of ECE curriculum for a } \\
\text { certain period of time. }\end{array}$ \\
\hline 2 & CONTENT STANDARDS & $\begin{array}{l}\text { 1. The religious and moral aspects of learning focus on tolerance, } \\
\text { because now children tend to be introduced deeply to certain religions } \\
\text { and without regard to the diversity of religions and cultures in } \\
\text { Indonesia. } \\
\text { 2. Institutions are given the freedom to develop themes and sub-themes } \\
\text { for ECE institutions with the development of each institution so that } \\
\text { creative institutions in formulating themes and sub-themes are } \\
\text { tailored to the needs of each institution's achievement. } \\
\text { 3. Determination of themes and sub-themes which later become } \\
\text { materials for learning activities to the flow of information/science } \\
\text { should be contextual in accordance with the stages of child } \\
\text { development. } \\
\text { Development of materials for the development of learning in ECE } \\
\text { institutions is developed based on the needs of each institution, so that } \\
\text { each of them has the characteristics in accordance with its vision and } \\
\text { mission. }\end{array}$ \\
\hline 3 & PROCESS STANDARDS & $\begin{array}{l}\text { 1. Creating a framework for learning in ECE institutions so that activities } \\
\text { become creative and can be practiced directly by both children and } \\
\text { teachers in ECE institutions. } \\
\text { 2. The learning process is institutionalized by ECE, Institutions, parents, } \\
\text { communities, and the government to participate in supervising and } \\
\text { getting involved in it. Institutions see and restore the nature of } \\
\text { children. Learning is adapted to the child's capacity. } \\
\text { 3. There needs to be a technology-based system that can monitor the }\end{array}$ \\
\hline
\end{tabular}

The learning process must be held interactively, inspirational, fun, challenging, so as to motivate students to actively participate and provide adequate space for initiative, creativity and independence in accordance with the talents, interests and physical and psychological development of students. The learning process will be optimal if it is supported by an approach that suits the children's needs and interests.

Early childhood education institutions, strive to provide the best service to improve the quality of their institutions. Every ECE institution has different benchmarks for the quality of its institutions. The formulation of the portrait of rural ECE quality after one village one ECE policy program, based on Ministry of Education and Culture Regulation standards No. 137 of 2014 which is used as a reference for developing ECE services according to national standards 


\begin{tabular}{|c|c|c|c|}
\hline & & & $\begin{array}{l}\text { sustainability of the ECE institution process. } \\
\text { Rural ECE is synonymous with a more prominent local culture, if it } \\
\text { needs to be included in the content standard, see a rapid cultural shift } \\
\text { consumed by the flow of technology. } \\
\text { Planning in ECE institutions can be made as simple as possible, so } \\
\text { that the teacher's time is not drained in making the administration. } \\
\text { Children have the right to make plans for what children can/want to } \\
\text { play in the institution/class. So children plan what they will do in one } \\
\text { day at the institution. }\end{array}$ \\
\hline 4 & $\begin{array}{l}\text { ASSESSMENT } \\
\text { STANDARDS }\end{array}$ & & $\begin{array}{l}\text { The process of assessing children's learning outcomes in accordance } \\
\text { with clear and transparent development stages is attached by } \\
\text { authentic evidence and given to parents through the results of child } \\
\text { development reports. } \\
\text { Standard of assessment, in the assessment instrument can be added to } \\
\text { the assessment rubric. So the observation of children's development is } \\
\text { not based on carelessness when determining the criteria for BB, MB, } \\
\text { BSH, and BSB. } \\
\text { Report of the assessment results is not only reported to the parents of } \\
\text { the student guardian but is given to the relevant agency to be used as } \\
\text { an evaluation of the learning activity program. } \\
\text { Make a school web that can be accessed by a student and can display } \\
\text { all information about the school and each student's guardian has a } \\
\text { username/password to find out their children's development. } \\
\text { ECE institutions need to pay attention to assessment mechanisms that } \\
\text { are not rigid and brave to develop by themselves according to the } \\
\text { needs of the institution. } \\
\text { Assessment techniques need to be considered not only in the form of } \\
\text { administrative documents, but need to choose the most appropriate } \\
\text { technique for early childhood }\end{array}$ \\
\hline 5 & $\begin{array}{l}\text { EDUCATORS AND } \\
\text { EDUCATION } \\
\text { PERSONNEL } \\
\text { STANDARDS }\end{array}$ & & $\begin{array}{l}\text { The qualifications of educators are developed according to the current } \\
\text { development of education and certified as professional teachers. } \\
\text { Educators who are not yet linear, are given a lot of training, } \\
\text { workshops, or are required to take the appropriate education level and } \\
\text { take professional education. }\end{array}$ \\
\hline 6 & $\begin{array}{l}\text { FACILITIES AND } \\
\text { INFRASTRUCTURE } \\
\text { STANDARDS }\end{array}$ & & $\begin{array}{l}\text { Standard facilities and infrastructure in supporting quality ECE can be } \\
\text { added to the infirmary, consultancy room with a psychologist or } \\
\text { doctor. } \\
\text { Having open and comfortable space to improve children's } \\
\text { performance and abilities. } \\
\text { There is attention and investment assistance from the company/ } \\
\text { government so that ECE infrastructure facilities increase, besides that } \\
\text { it is supplemented by the local wisdom of each region / ECE. } \\
\text { Safety standards must be a priority in addition to the completeness of } \\
\text { their own facilities. } \\
\text { Equalization of early childhood education institutions in rural areas to } \\
\text { meet the required standards } \\
\text { The need to establish private and state ECE institutions in rural areas } \\
\text { to stimulate children's growth and development. }\end{array}$ \\
\hline 7 & $\begin{array}{l}\text { MANAGEMENT } \\
\text { STANDARDS }\end{array}$ & & $\begin{array}{l}\text { There is an adjustment about the ratio of students and teachers so that } \\
\text { the distribution of student quota in schools can be done well } \\
\text { The role of parents as school committees in the management of } \\
\text { educational needs in the form of inputs of academic value to support } \\
\text { quality ECE. } \\
\text { Supervision of school/ institution programs is further enhanced and } \\
\text { carried out continuously to achieve quality ECE goals. } \\
\text { There are periodic reviews conducted by institutions, foundations, } \\
\text { parents of children looking back on their vision, mission, and their } \\
\text { existing goals, whether they are in line with ECE goals. } \\
\text { It is necessary to add professionals such as psychologists, doctors/ } \\
\text { medical personnel and those who are competent in ECE who are part }\end{array}$ \\
\hline
\end{tabular}




\begin{tabular}{|c|l|r|}
\hline & & $\begin{array}{l}\text { of the team that carries out ECE management and this requires } \\
\text { government support. }\end{array}$ \\
\hline $\mathbf{8}$ & FINANCING & 1. $\begin{array}{l}\text { There are regular and certain corporate and CSR assistance from the } \\
\text { government. The government and ECE institutions collaborate with } \\
\text { STANDARDS }\end{array}$ \\
2. & ECE teacher calaries must at least meet the minimum wage standard. \\
\hline
\end{tabular}

From the above table, the data about the portrait of the quality of rural ECE is obtained. The portrait of the quality of rural ECE is a barometer of ECE progress at a broader level such as urban and generally at the national level that supports the vision of one village one ECE movement.

ECE is very important and must be handled by professionals, early childhood education is also the most profitable investment in human capital (Heckman in Formen, 2012). The emergence of various early childhood education services at various levels and types of early childhood education in rural areas is an important part of the participation of rural communities in the investment of human resources carried out early so that children in the future become extraordinary assets in national development, especially development in rural areas.

The collaboration between ECE institutions, the education office, village government and the community is very much expected, this is a manifestation of the involvement of all components in the development of rural ECE. The lack of participation from all parties can have an impact on the delay in the construction of quality rural ECE.

In addition, family participation is very important and needed, because the initial process of child growth and development from the family environment, then early childhood education institutions must also include parents in educating children. As parents are the ones who are responsible for their children, parental participation holds an important function and role in the sustainability of early childhood education.

\section{CONCLUSION}

The portrait of rural ECE in the digital era requires the synergy of all interested parties in the hope of providing facilitation so that stimulation programs for children development as an investment in human resources early on can work well. A common awareness emerged in educating young people in the countryside, is a very valuable investment and capital in the birth of rural development fighters.

\section{REFERENCES}

[1] Blaise, M. (2005). Playing It Straight: Uncovering Gender Discourse in The Early Childhood Classroom. New York: Routledge.

[2] Farquhar, S.-E. J. (1993). Constructions of Quality in Early Childhood Centers. Unpublished Doctoral Thesis, University of Otago.

[3] Formen, A. (2008). The Political Landscape of Early Childhood Education in Indonesia. Unpublished Master Thesis, Monash University, Melbourne.

[4] Formen, A. (2012) Kebijakan ECE di Indonesia. Paper Un Publish, Semarang

[5] Gutama. (2006). Pendidikan Anak Usia Dini (ECE) sebagai Starting Point Pengembangan Kecerdasan SDM untuk Mewujudkan Generasi Bangsa yang Berpengetahuan dan Beradab. Paper presented at the Kuliah Umum Kampus STKIP Kie Raha Ternate, Maluku Utara, Indonesia, August 27, 2006.

[6] Kerangka Besar (2013) Pembangunan ECE Terpadu dengan Pendekatan Holistik Integratif Provinsi Jawa Tengah.

[7] Peraturan Menteri Desa, Pembangunan Daerah Tertinggal, dan Transmigrasi Republik Indonesia Nomor 22 Tahun 2016 Tentang Penetapan Prioritas Penggunaan Dana Desa tahun 2017.

[8] PP No 32 tahun 2013 Tentang Standar Nasional Pendidikan

[9] Undang-undang No. 6 tahun 2014, tentang Desa 